\title{
Variability Studies on Sheath Blight of Rice in Karnataka, India
}

\author{
O. Manjunatha ${ }^{1 *}$, B. Vidya Sagar ${ }^{1}$, V. Prakasam ${ }^{2}$ and C.N. Narendra Reddy ${ }^{1}$
}

${ }^{1}$ Department of Plant Pathology, College of Agriculture, Acharya N.G. Ranga Agricultural University, Rajendranagar, Hyderabad - 500 030, Telangana, India

${ }^{2}$ Department of Plant Pathology, Indian Institute of Rice Research, Rajendranagar, Hyderabad - 500 030, Telangana, India

*Corresponding author

\section{A B S T R A C T}

\begin{tabular}{|l|}
\hline K e y w o r d s \\
Rhizoctonia solani Kühn \\
[Teleomorph: \\
Thanatephorus cucumeris \\
(Frank) Donk]
\end{tabular}

\section{Introduction}

Sheath blight of rice caused by Rhizoctonia solani [Teleomorph: Thanatephorus cucumeris (Frank) Donk] is one of the major biotic constraints in India and reduce rice yield ranging from $20-50 \%$ depending on the severity of the disease and stages of infection. The disease has spread widely in terms of both occurrence and intensity over past 20 years. At present it is one of the major production constraints in the states of Punjab, Haryana, Uttarakhand, Eastern Uttar Pradesh, Bihar, West Bengal, Odisha, Chhattishgarh, coastal areas of Andhra Pradesh, Tamil Nadu and Kerala and parts of Karnataka. The $R$. solani emerged as an economically important rice pathogen, due to the intensification of ricecropping systems with the development of new dwarf, high-tillering, high yielding varieties, high plant densities and an increase in nitrogen fertilization. These factors promote disease spread by providing a favorable microclimate, due to a denser leaf canopy with an increased leaf-to leaf and leaf-to-sheath contact. Breeding for sheath blight resistant cultivars has been a priority area in India. However lack of resistant donors, nonavailability of markers and lack of adequate information on the genetic variability of fungal population are some of the limiting factors for developing suitable strategies for 
control measures (Neeraja et al., 2002). Further, the fungus has worldwide distribution (Ogoshi, 1987) and isolates of $R$. solani are highly variable in aggressiveness. Although earlier studies suggested that AG-1 IA represented a homogenous group of $R$. solani (Kuninga and Yokosawa, 1982), recent investigations support the hypothesis that the sheath blight pathogen is far more diverse than previously assumed (Neeraja et al., 2002; Singh et al., 2002; Yu et al., 2003; Susheela et al., 2004). Bridge et al., (1995) concluded that integration of genetic techniques with functional characters could provide a powerful tool for characterization of fungal plant pathogens, particularly in respect of host and cultivar-specific populations such as weeds.

\section{Materials and Methods}

\section{Isolation of the pathogen, pathogenicity and maintenance of the pathogen}

Leaves or leaf sheath showing characteristic sheath blight symptom were collected from major rice growing areas of Karnataka, India (Table 1). Infected plant tissues are cut into pieces of $5 \mathrm{~cm}$, washed in running tap water to eliminate any attached organic debris and blotted dry. Small samples of plant tissue $(0.5$ $\mathrm{cm}$ of length) are then cut from the lesions and transferred to an isolation medium i.e., $2 \%$ water agar. The plates are then incubated for 24-48 hrs at 28-30 ${ }^{\circ} \mathrm{C}$. Mycelial tips with morphological characters typical of $R$. solani, growing out from the infected plant tissues are cut, put in fresh Potato Dextrose Agar (PDA) plates and maintained in PDA slants at $4{ }^{\circ} \mathrm{C}$.

\section{Morphological and cultural characterization}

For studying morphological and cultural characterization the isolates were inoculated on PDA medium. The $20 \mathrm{ml}$ medium was poured into each $90 \mathrm{~mm}$ petri plate and inoculated with 5 day old inoculum of $5 \mathrm{~mm}$ disc by placing in centre of the Petri dish. Three replications for each isolate were maintained. The inoculated plates were incubated at $27 \pm 1^{\circ} \mathrm{C}$. Mycelial and sclerotial parameters were recorded for each isolate.

\section{Pathogenic variability}

Plants of the susceptible cultivar (TN-1) were inoculated at tillering stage with Typha bits colonized with $R$. solani, and were maintained in the glass house at $75-90 \%$ relative humidity. The disease incidence and disease severity were recorded 7 days after inoculation, by measuring number of tillers affected, plant height and lesion height. Three replications for each isolates were maintained.

\section{DNA extraction and purification}

Fungal DNA was extracted following the method of George et al., (1998)

\section{RAPD analysis}

Initially screened 25 RAPD RBa primers of which 10 primers yielded scorable and reproducible banding patterns were selected for further study. The reaction mixture composition for the polymerase chain reaction was $25 \mu \mathrm{l}$, containing $2.0 \mu \mathrm{l} 10 \mathrm{x}$ Taq Buffer A, $1.0 \mu 12.5 \mathrm{mM}$ dNTPs, $1.0 \mu \mathrm{l}$ Primer, $1.0 \mu \mathrm{l}$ $\mathrm{MgCl}_{2}$ and $0.3 \mu \mathrm{T}$ Taq polymerase (all from Bangalore Genei, India). Then, $20 \mu \mathrm{l}$ of master mix was added to another tube containing $1.5 \mu \mathrm{l}$ of template DNA and a spin was given. The thermo cycling profile consisted of 1 cycle of initial denaturation at $95^{\circ} \mathrm{C}$ for $5 \mathrm{~min}$ followed by 35 cycles of $94^{\circ} \mathrm{C}$ for $1 \mathrm{~min}$ (denaturation), $36^{\circ} \mathrm{C}$ for $1 \mathrm{~min}$ (primer annealing), $72^{\circ} \mathrm{C}$ for $2 \mathrm{~min}$ (extension), followed by a final extension at $72^{\circ} \mathrm{C}$ for $5 \mathrm{~min}$. The amplified DNA samples were electrophoresed on $2.0 \%$ agarose gel in 1x TAE buffer stained with ethidium bromide 
along with $1 \mathrm{~kb}$ DNA ladder and visualized under Gel Documentation System (GDS) (AlphaImager, USA).

\section{ISSR analysis}

Fifty ISSR primers obtained from University of British Columbia website used for the study and found that 10 primers yielded scorable and reproducible banding patterns. These were selected for studying genetic variability. Amplification reactions were performed in a $25 \mu \mathrm{l}$ volume containing $2.0 \mu \mathrm{l} 10 \mathrm{x}$ Taq Buffer A, $1.0 \mu \mathrm{l} 2.5 \mathrm{mM}$ dNTPs, $1.0 \mu \mathrm{l}$ primer, $1.0 \mu \mathrm{l} \mathrm{MgCl}_{2}, 0.3 \mu \mathrm{l}$ Taq polymerase (3u) (from Bangalore Genei) and $14.0 \mu \mathrm{l}$ of Milli- Q- Water. The optimized PCR analysis was performed using a VeritiTM 96 gradient thermal cycler (Applied Biosystems, CA, USA) with the following amplification conditions: 1 cycle of initial denaturation at $95^{\circ} \mathrm{C}$ for 5 min followed by 30 cycles of $94^{\circ} \mathrm{C}$ for $1 \mathrm{~min}$ (denaturation), $36^{\circ} \mathrm{C}$ for $1 \mathrm{~min}$ (primer annealing), $72^{\circ} \mathrm{C}$ for $2 \mathrm{~min}$ (extension), followed by a final extension at $72^{\circ} \mathrm{C}$ for $5 \mathrm{~min}$. The amplified DNA samples were electrophoresed on $2.0 \%$ agarose gel in 1x TAE buffer stained with ethidium bromide along with $1 \mathrm{~kb}$ DNA ladder and visualized under Gel Documentation System.

\section{Results and Discussion}

\section{Morphological and cultural characterization}

All the 20 isolates were grouped based on mycelial and sclerotial characters as per Lal et al., (2014) and Upadhyay et al., (2013). Morphological studies of the isolates showed wide variability in angle mycelial growth, mycelial width and distance between two septation. The isolate RS-K-17 branched at maximum degrees of angle $\left(96.15^{\circ}\right)$ followed by RS-K-12(93.84 $)$, RS-K-1 $\left(93.74^{0}\right)$ and RSK-9 $\left(93.49^{\circ}\right.$ ) (Table 1 and Fig. 1). Most of isolates branched at nearly $90^{\circ}$. It was an obvious observation for the mycelial branching at right angles as a known feature of R. solani (Sneh et al., 1991). Lal et al., (2014) described that 25 isolates of $R$. solani and all the isolates exhibited typical hyphal branching at right angle. The perusal of data presented in Table 1 showed that the hyphal width of all the twenty isolates varied from 1.80 (RS-K20) to $9.43 \mu \mathrm{m}$ (RS-K-4). The maximum distance between the septation was observed in the isolate RS-K-11(351.92 $\mu \mathrm{m})$ and isolate RS-K-18 showed minimum septation distance $(15.37 \mu \mathrm{m})$. It was an obvious observation for the mycelium branching out at right angles, hyphal width 1.80 to $9.43 \mu \mathrm{m}$ and distance between two septation were visualized under light microscopy and these were the characters of immense taxonomical importance which were described by the previous workers Duggar (1915), Matsumato (1921), Singh et al., (2014) and Moni et al., (2016).

\section{Cultural variability}

The details pertaining to cultural variability were presented in the Table 2 . The colony color varied from Ivory to pale brown. Based on reverse surface color on the petri-plate 20 $R$. solani isolates were classified into three categories viz., Ivory, sand yellow and olive green. Zhang et al., (1995) allocated turf grass isolates of $R$. solani to different AG groups based on colony pigmentation. Similarly, Lal et al., (2014) categorized $R$. solani isolates causing Sheath blight disease into five groups based on colony color. Distinct differences were observed in the colony appearance. The colony texture varied from highly dense texture i.e., fluffy, flat plain and slightly fluffy mycelial growth. Distinct differences were observed in the colony appearance and the isolates were categorized into different groups based on texture and abundance of mycelium. Based on growth rate all the 20 isolates were categorized mainly into three groups viz., slow 
growing $(1.8-2.0 \mathrm{~mm} / \mathrm{h})$, medium growing (2.0-2.2 $\mathrm{mm} / \mathrm{h})$ and fast growing $(\geq 2.2 \mathrm{~mm} / \mathrm{h})$. Similar observations had been made by Toda et al., (1999) who divided $R$. solani AG-D isolates into two subgroups AG-D (I) and AG$\mathrm{D}$ (II), based on the results of cultural characteristics. Guleria et al., (2007) used cultural characters for differentiating the $R$. solani isolates from rice. Thind and Aggarwal (2008), Khodaryari et al., (2009) and Guleria et al., (2007) stated that the $R$. solani isolates from rice were fast growing with $>20 \mathrm{~mm}$ mycelial growth rate per day indicating their fast growing nature. Rapid growth rate among $R$. solani isolates have also been reported by Lal et al., (2014) and Upadhyay et al., (2013).

Table.1 Morphological characters of Rizhoctonia solani isolates from Karnataka

\begin{tabular}{|c|c|c|c|c|}
\hline $\begin{array}{l}\text { S. } \\
\text { No }\end{array}$ & Isolates & Mycelial width (in $\mu \mathrm{m}$ ) & Angle of branching $\left({ }^{0} 0\right)$ & $\begin{array}{l}\text { Distance between septation (in } \\
\mu \mathrm{m})\end{array}$ \\
\hline 1 & RS-K-01 & $5.48^{\mathrm{cd}}$ & 93.74 & $105.64^{\mathrm{e}}$ \\
\hline 2 & RS-K-02 & $8.96^{\mathrm{ab}}$ & $74.09^{\mathrm{a}}$ & $080.86^{\mathrm{f}}$ \\
\hline 3 & RS-K-03 & $8.80^{\mathrm{ab}}$ & $78.02^{\mathrm{a}}$ & $109.43^{\mathrm{de}}$ \\
\hline 4 & RS-K-04 & $9.43^{\mathrm{a}}$ & $68.30^{\mathrm{a}}$ & $229.01^{\mathrm{b}}$ \\
\hline 5 & RS-K-05 & $8.06^{b}$ & $87.89^{b}$ & $119.97^{\mathrm{d}}$ \\
\hline 6 & RS-K-06 & $8.09^{\mathrm{b}}$ & $86.30^{b}$ & $169.45^{\mathrm{c}}$ \\
\hline 7 & RS-K-07 & $9.30^{\mathrm{a}}$ & $90.65^{b}$ & $078.58^{\mathrm{f}}$ \\
\hline 8 & RS-K-08 & $8.48^{\mathrm{ab}}$ & 80.16 a & $057.16^{\mathrm{gh}}$ \\
\hline 9 & RS-K-09 & $2.41^{\mathrm{e}}$ & $93.49^{b}$ & $187.08^{\mathrm{c}}$ \\
\hline 10 & RS-K-10 & $2.25^{\mathrm{e}}$ & $86.84^{b}$ & $056.41^{\mathrm{gh}}$ \\
\hline 11 & RS-K-11 & $8.63^{\mathrm{ab}}$ & $74.53^{\mathrm{a}}$ & $351.92^{\mathrm{a}}$ \\
\hline 12 & RS-K-12 & $8.94^{\mathrm{ab}}$ & $93.84^{\mathrm{b}}$ & $045.35^{\mathrm{i}}$ \\
\hline 13 & RS-K-13 & $9.02^{\mathrm{ab}}$ & $84.42^{b}$ & $107.31^{\text {de }}$ \\
\hline 14 & RS-K-14 & $2.38^{\mathrm{e}}$ & $78.62^{\mathrm{a}}$ & $062.51^{\mathrm{g}}$ \\
\hline 15 & RS-K-15 & $6.15^{\mathrm{c}}$ & $91.54^{\mathrm{b}}$ & $252.23^{\mathrm{b}}$ \\
\hline 16 & RS-K-16 & $5.03^{\mathrm{d}}$ & $89.72^{b}$ & $052.03^{\mathrm{hi}}$ \\
\hline 17 & RS-K-17 & $1.92^{\mathrm{e}}$ & $96.15^{b}$ & $057.03^{\mathrm{gh}}$ \\
\hline 18 & RS-K-18 & $2.44^{\mathrm{e}}$ & $86.87^{b}$ & $015.37^{\mathrm{j}}$ \\
\hline 19 & RS-K-19 & $2.41^{\mathrm{e}}$ & $83.99^{b}$ & $164.44^{\mathrm{c}}$ \\
\hline \multirow[t]{3}{*}{20} & RS-K-20 & $1.80^{\mathrm{e}}$ & $87.76^{\mathrm{b}}$ & $064.69^{\mathrm{g}}$ \\
\hline & C.D. $(P=0.05)$ & 1.05 & 21.56 & 0.06 \\
\hline & C.V $(\%)$ & 10.56 & 15.18 & 1.97 \\
\hline
\end{tabular}


Table.2 Cultural characteristics of Rhizoctonia solani isolates collected from rice growing areas of Karnataka

\begin{tabular}{|c|c|c|c|c|c|c|}
\hline Isolates & $\begin{array}{l}\text { Surface color } \\
\text { of the culture } \\
\text { plate }\end{array}$ & $\begin{array}{l}\text { Reverse color of } \\
\text { the culture plate }\end{array}$ & Mycelial color & Arrangement of sclerotia & Texture & $\begin{array}{l}\text { Honey } \\
\text { dew } \\
\text { secretion }\end{array}$ \\
\hline RS-K-1 & Ivory & Sand yellow & Cream & Concentric rings & Fluffy & - \\
\hline RS-K-2 & Olive grey & Sand Yellow & White & Lower and peripheral ring & Flat plain & + \\
\hline RS-K-3 & Sand yellow & Sand yellow & Oyster white & Grouped at centre & Flat plain & - \\
\hline RS-K-4 & Sand yellow & Sand Yellow & Cream & Scattered grouping & Slightly fluffy & + \\
\hline RS-K-5 & Sand yellow & Sand yellow & Cream & $\begin{array}{l}\text { Grouped at centre and peripheral } \\
\text { ring }\end{array}$ & Fluffy & + \\
\hline RS-K-6 & Pale brown & Ivory & White & Lower ring & Slightly fluffy & + \\
\hline RS-K-7 & Sand yellow & Sand Yellow & Signal white & Lower ring & Flat plain & - \\
\hline RS-K-8 & Sand yellow & Olive Grey & Light ivory & Scattered grouping & Slightly fluffy & - \\
\hline RS-K-9 & Pale brown & Ivory & Cream & Grouped at centre & Slightly fluffy & + \\
\hline RS-K-10 & Pale brown & Sand Yellow & Cream white & Scattered grouping & Fluffy & + \\
\hline RS-K-11 & Olive grey & Olive Grey & Cream & Grouped at centre & Slightly fluffy & - \\
\hline RS-K-12 & Sand Yellow & Sand yellow & White & Lower ring & Slightly fluffy & - \\
\hline RS-K-13 & Ivory & Ivory & Oyster white & Middle and peripheral ring & Slightly fluffy & - \\
\hline RS-K-14 & Pale brown & Ivory & White & Scattered grouping & Flat plain & - \\
\hline RS-K-15 & Sand Yellow & Olive Grey & White & Middle ring & Flat plain & - \\
\hline RS-K-16 & Ivory & Ivory & White & Grouped at centre, peripheral ring & Slightly fluffy & + \\
\hline RS-K-17 & Ivory & Ivory & Oyster white & Grouped at centre & Slightly fluffy & + \\
\hline RS-K-18 & Sand Yellow & Sand yellow & Light ivory & Middle ring & Flat plain & + \\
\hline RS-K-19 & Sand yellow & Sand Yellow & Cream & $\begin{array}{l}\text { Grouped at centre, Scattered } \\
\text { grouping }\end{array}$ & Slightly fluffy & - \\
\hline RS-K-20 & Ivory & Sand Yellow & Sand Yellow & Grouped at centre & Slightly fluffy & - \\
\hline
\end{tabular}


Table.4 Pathological variation among $R$. solani isolates collected from major rice growing areas of Karnataka

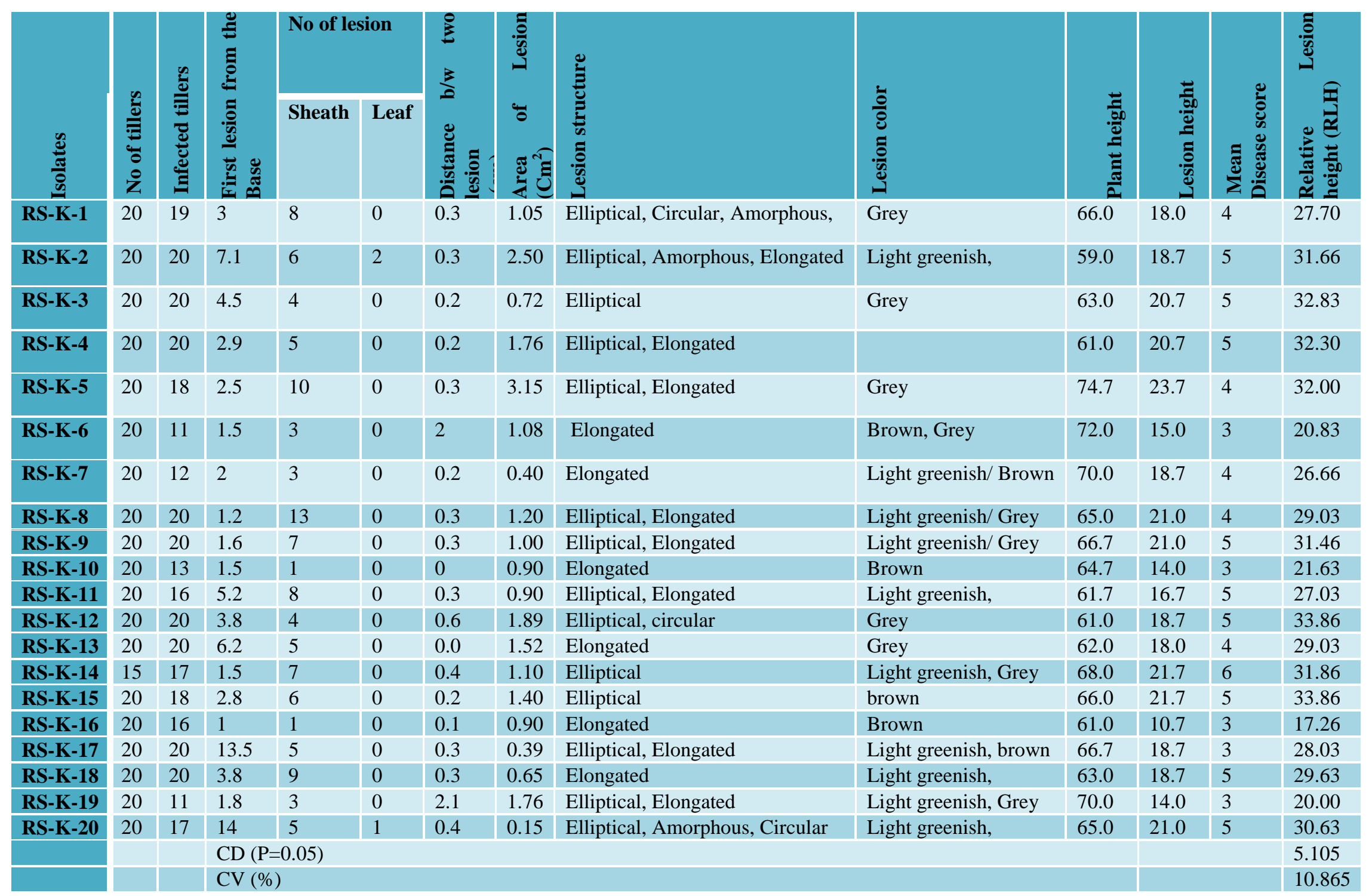


Table.3 Pathological variability of Rhizoctonia solani isolates collected from rice growing areas of Karnataka

\begin{tabular}{|l|l|l|l|}
\hline Sl. No. & Isolates & RLH & Disease incidence \\
\hline $\mathbf{1}$ & RS-K-1 & 27.70 & $96.67(80.43)$ \\
\hline $\mathbf{2}$ & RS-K-2 & 31.66 & $100.00(87.13)$ \\
\hline $\mathbf{3}$ & RS-K-3 & 32.83 & $100.00(87.13)$ \\
\hline $\mathbf{4}$ & RS-K-4 & 32.30 & $100.00(87.13)$ \\
\hline $\mathbf{5}$ & RS-K-5 & 32.00 & $90.00(74.04)$ \\
\hline $\mathbf{6}$ & RS-K-6 & 20.83 & $83.33(65.95)$ \\
\hline $\mathbf{7}$ & RS-K-7 & 26.66 & $58.33(49.80)$ \\
\hline $\mathbf{8}$ & RS-K-8 & 29.03 & $100.00(87.13)$ \\
\hline $\mathbf{9}$ & RS-K-9 & 31.46 & $100.00(87.13)$ \\
\hline $\mathbf{1 0}$ & RS-K-10 & 21.63 & $65.00(53.72)$ \\
\hline $\mathbf{1 1}$ & RS-K-11 & 27.03 & $78.33(62.29)$ \\
\hline $\mathbf{1 2}$ & RS-K-12 & 33.86 & $100.00(87.13)$ \\
\hline $\mathbf{1 3}$ & RS-K-13 & 29.03 & $100.00(87.13)$ \\
\hline $\mathbf{1 4}$ & RS-K-14 & 31.86 & $55.00(47.87)$ \\
\hline $\mathbf{1 5}$ & RS-K-15 & 33.86 & $90.00(71.56)$ \\
\hline $\mathbf{1 6}$ & RS-K-16 & 17.26 & $80.00(63.93)$ \\
\hline $\mathbf{1 7}$ & RS-K-17 & 28.03 & $98.33(83.78)$ \\
\hline $\mathbf{1 8}$ & RS-K-18 & 29.63 & $100.00(87.13)$ \\
\hline $\mathbf{1 9}$ & RS-K-19 & 20.00 & $56.67(48.83)$ \\
\hline $\mathbf{2 0}$ & RS-K-20 & 30.63 & $85.00(67.40)$ \\
\hline C.D. & & 5.105 & 6.37 \\
\hline C.V. & & 10.865 & 5.26 \\
\hline & & & \\
\hline
\end{tabular}

Table.5 Details of the primers, polymorphism and banding patterns of 20 isolates of Rhizoctonia solani by 10 RAPD primers

\begin{tabular}{|l|l|l|l|l|l|}
\hline $\begin{array}{l}\text { RAPD } \\
\text { Primers (RBa) }\end{array}$ & $\begin{array}{l}\text { No. of } \\
\text { loci }\end{array}$ & $\begin{array}{l}\text { No. } \\
\text { polymorphic } \\
\text { loci }\end{array}$ & Polymorphism \% & PIC & $\begin{array}{l}\text { Mean } \\
\text { Genetic } \\
\text { similarity }\end{array}$ \\
\hline $\mathbf{2}$ & 12 & 12 & 100.00 & 0.8778 & 0.31 \\
\hline $\mathbf{3}$ & 7 & 7 & 100.00 & 0.8244 & 0.29 \\
\hline $\mathbf{5}$ & 12 & 12 & 100.00 & 0.8733 & 0.36 \\
\hline $\mathbf{6}$ & 8 & 8 & 100.00 & 0.8362 & 0.38 \\
\hline $\mathbf{8}$ & 8 & 8 & 100.00 & 0.8520 & 0.57 \\
\hline $\mathbf{9}$ & 16 & 16 & 100.00 & 0.8668 & 0.29 \\
\hline $\mathbf{1 3}$ & 10 & 10 & 100.00 & 0.8519 & 0.33 \\
\hline $\mathbf{2 0}$ & 10 & 10 & 100.00 & 0.8633 & 0.51 \\
\hline $\mathbf{2 2}$ & 11 & 11 & 100.00 & 0.8529 & 0.51 \\
\hline $\mathbf{2 3}$ & 8 & 8 & 100.00 & 0.8318 & 0.32 \\
\hline
\end{tabular}


Fig.1 Mycelial width and angle of branching of isolates collected from major rice growing areas of Karnataka

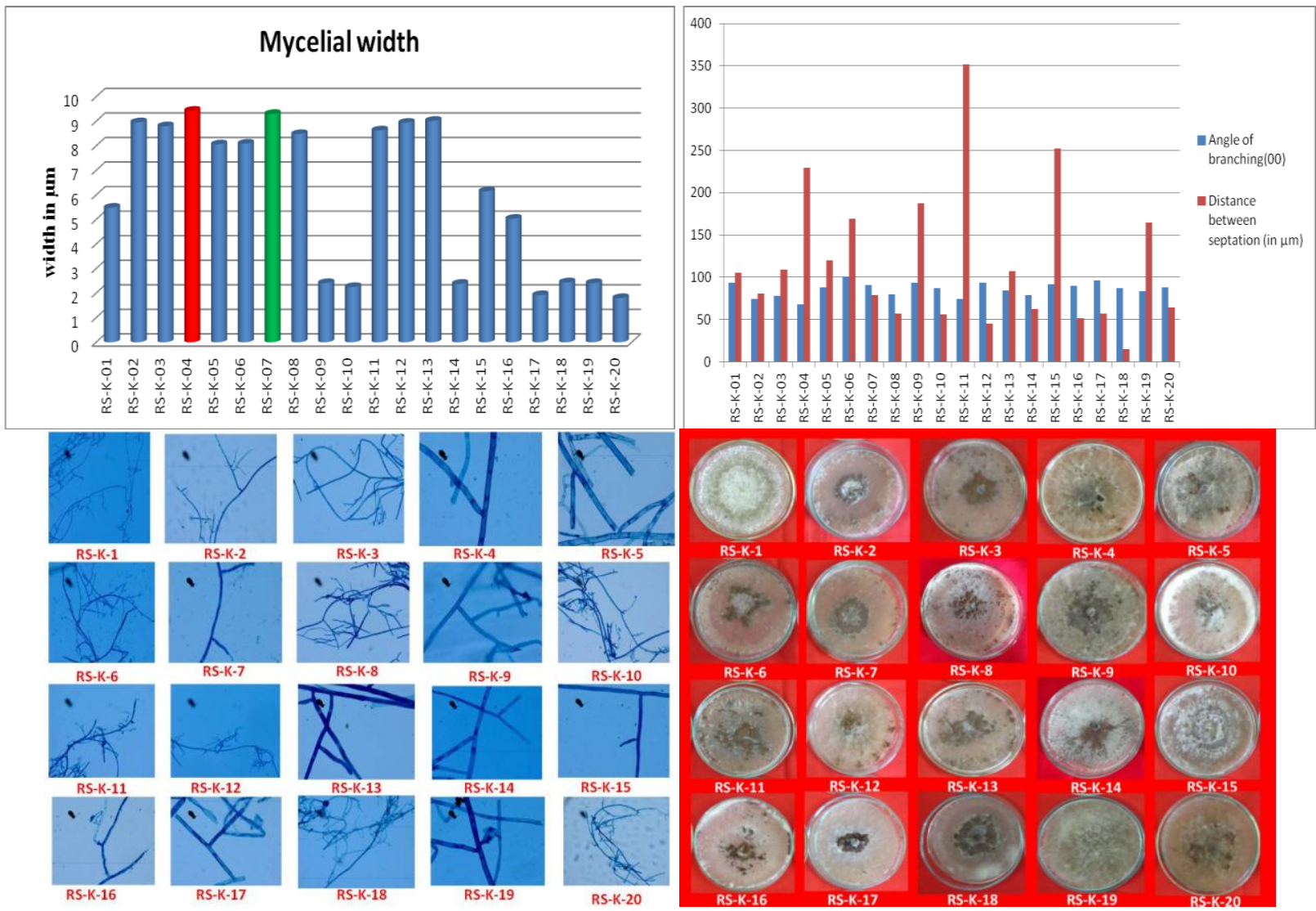

Fig.2 Electrophoretic banding pattern of 20 R. solani isolates of using RAPD primers, RBa-20

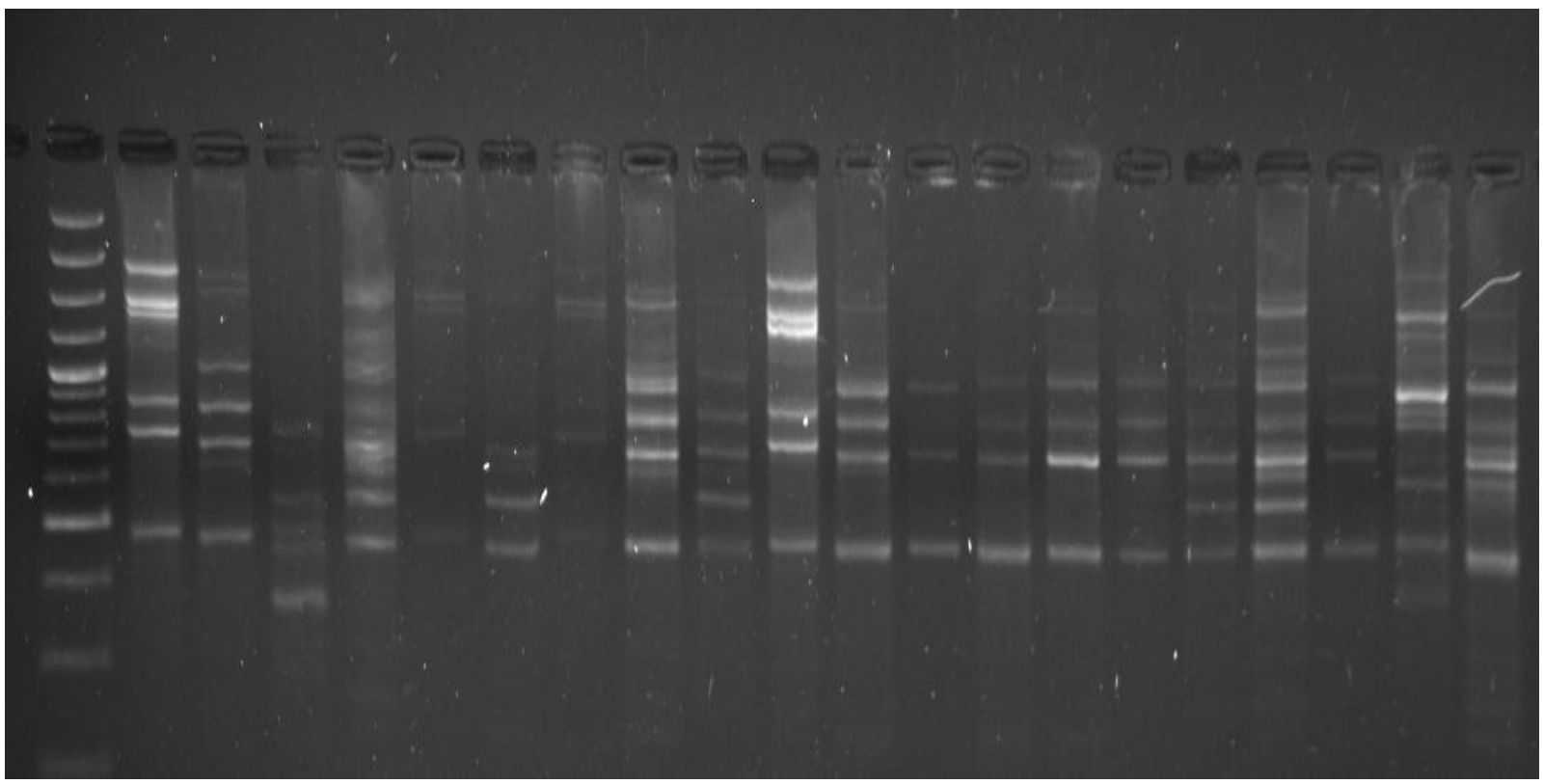


Fig.3 UPGMA dendrogram showing clustering of 20 isolates of $R$. solani using pooled RAPD

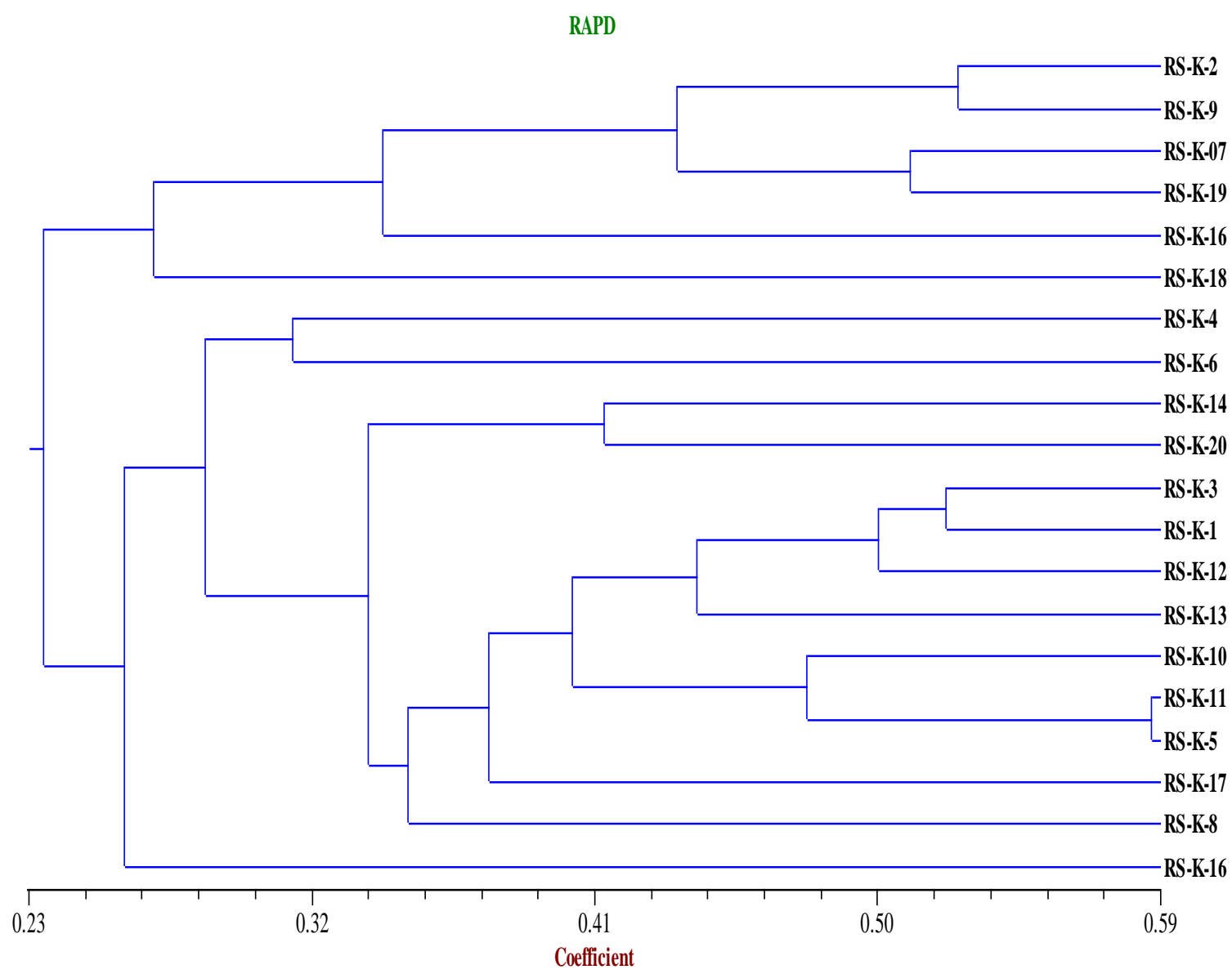

Fig.4 Electrophoretic banding pattern of $20 R$. solani isolates of using ISSR primers, UBC-808

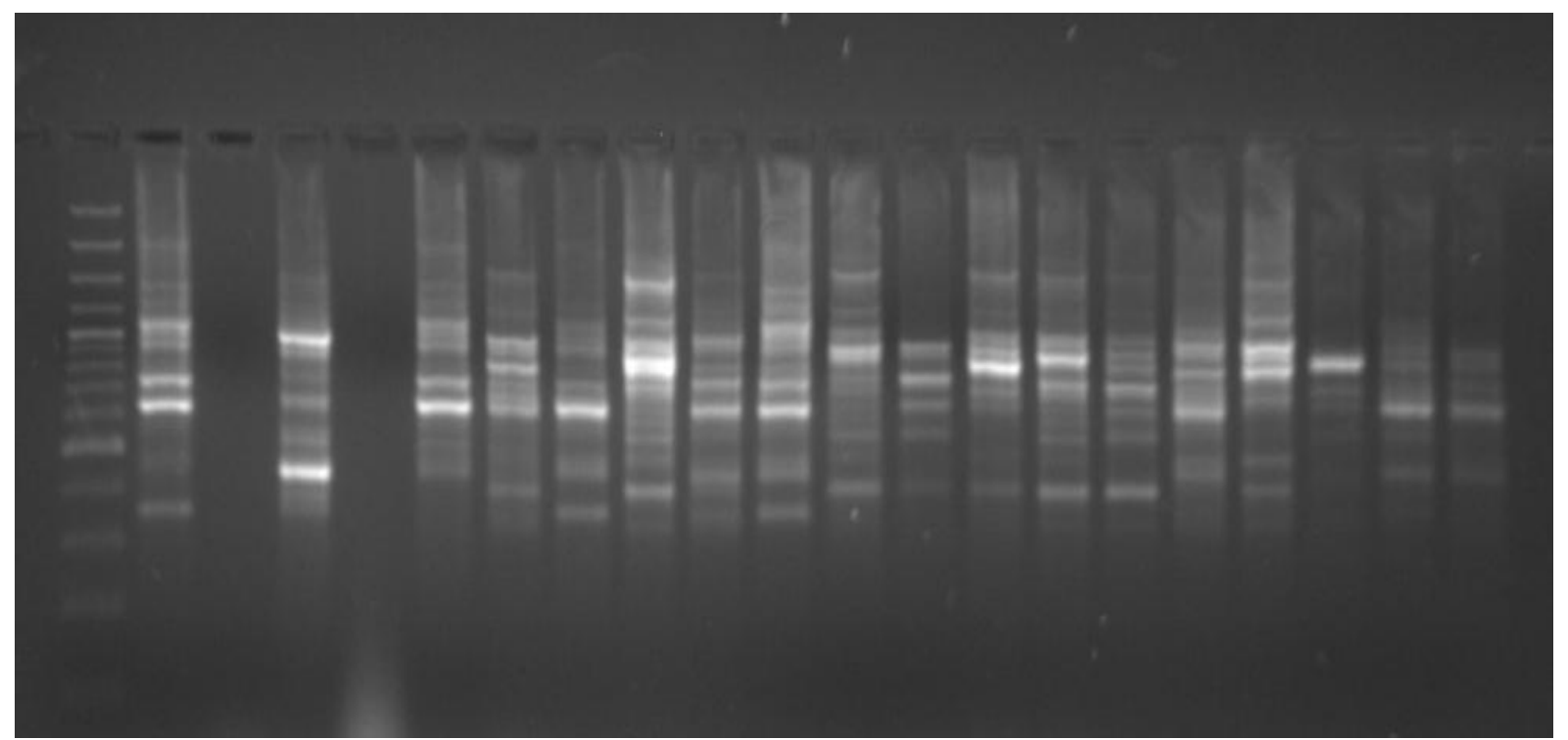


Fig.5 UPGMA dendrogram showing clustering of 20 isolates of $R$. solani using pooled ISSR

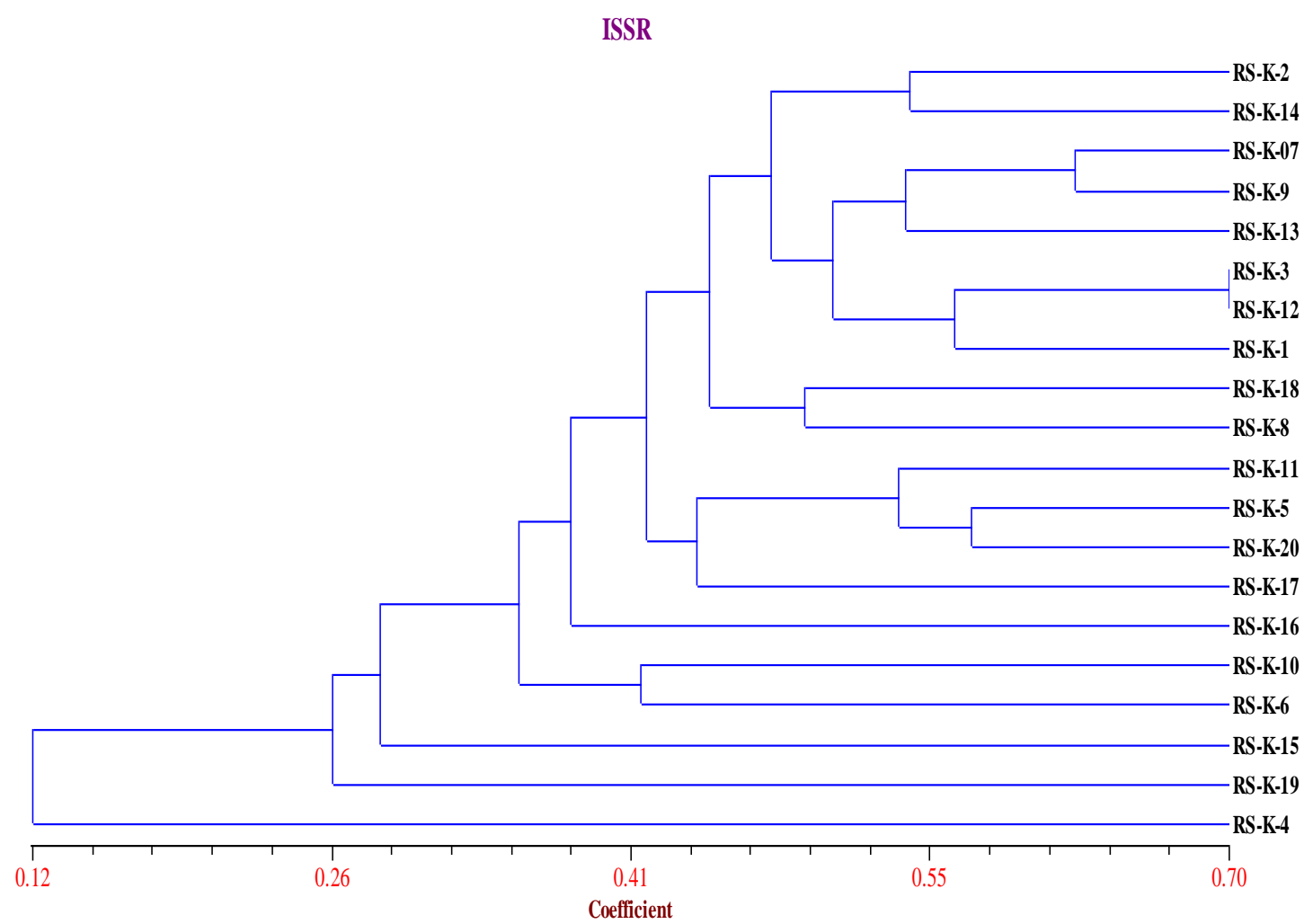

Based on pattern of sclerotial production 20 $R$. solani isolates were grouped into five categories viz., sclerotia grouped at centre(7), lower ring (3), middle ring (2), peripheral ring (4) and scattered (4). Among 20 R. solani isolates nine isolates secreted honey dew and others did not. However maximum number of sclerotia observed was 618 (RS-K-1), while minimum number of sclerotia was 67 (RS-K5). The sclerotial weight of 20 isolates ranged from 8.75 to $18.50 \mathrm{mg}$. Such type of categorization based on the pattern of formation and arrangement among rice $R$. solani isolates was done by Upadhyay et al., (2013) Thakur et al., (1992), Guleria et al., (2007) Singh et al., (2014) and Kumar et al., (2008).

\section{Pathological variability}

Pathological variability of $20 R$. solani isolates was studied on susceptible cv. TN-1 and found that isolates took 2-5 days to exhibit the typical sheath blight symptoms. And the size of the lesion ranged from 0.15$3.15 \mathrm{~cm}^{2}$, most of the isolates produced either elliptical or elongated lesions (Table 4). The disease severity varied from 17.26-33.86\%, among the isolates. All the twenty isolates were classified highly virulent (>50 \% DI) based on per cent disease incidence (Table 3 ). These results were in accordance with the findings of Swain et al., (2005) Nandi and Chakrabarthi (1984) Basu and Gupta (1992)

Xiao et al., (2008)

\section{Molecular variability}

Genetic diversity of $R$. solani isolates from different locations using 10 RAPD and ISSR primers showed good polymorphism at DNA level and cluster analysis of RAPD data grouped the isolates on the basis of their origin with few exceptions. A total of 102 
amplicons were obtained from twenty $R$. solani isolates with 10 RAPD primers of which $100 \%$ were polymorphic (Table 5). Cluster analysis of sheath blight isolates revealed the average pair-wise similarities in the range of 0.29-0.57 thus suggesting large variations among the isolates. In case of ISSR primers a total of 111 were obtained with 10 ISSR primers of which $95.92 \%$ were polymorphic. Cluster analysis revealed that 20 isolates grouped into two major clusters at $35 \%$ genetic similarity coefficient (Fig. 2-5). Similarity coefficient ranged from $0.30-0.50$ thus suggests good variations among the isolates. In the past, several studies were conducted for assessing molecular diversity in $R$. solani were conducted using RAPD based fingerprinting Sharma et al., (2005), Sundravadana et al., (2011) and Banerjee et al., (2012). Similar results were reported by Zhou et al., (2002), Yugander et al., (2015) who analysed genetic variability using ISSR primers.

\section{References}

Banerjee, S., Dutta, S., Mondal, A., Mandal, N., and Bhattacharya, S. 2012. Characterization of molecular variability in Rhizoctonia solani isolates from different agro-ecological zones by random amplified polymorphic DNA (RAPD) markers. African Journal of Biotechnology. 11 (40): 9543-9548.

Basu, A and Gupta, P.K.S. 1992 Cultural and pathogenic variation in rice isolates of Rhizoctonia solani Kuhn. Beitrage zur Tropischen Landwirtschaft and Veterinarmedizin. 30 (3): 291-297.

Bridge, P.D., Holderness, M., Paterson, R.R.M. and Rutherford, M. (1995). Multidisciplinary characterization of fungal plant pathogens. EPPO conference on New Methods of Diagnosis in Plant Protection 25: 125131.
Duggar, B.M. 1915. Rhizoctonia crocorrum (Pers.) DC and Rhizoctonia solani Kuhn (Corticium vagum $\mathrm{B} \& \mathrm{C}$ ) with notes on other species. Annuals of Missouri Botantanical Garden. 2: 403-458.

George, M.L.C., Nelso, R.J., Zeigler, R.S and Leung, H. 1998. Rapid population analysis of Magnaporthe grisea by using rep- PCR and endogenous repetitive DNA sequences. Phytopathology. 88: 223-229.

Guleria, S., Aggarwal, R., Thind, T.S and Sharma, T.R. 2007. Morphological and pathological variability in rice isolates of Rhizoctonia solani and molecular analysis of their genetic variability. Journal of Phytopathology. 155: 654661.

Khodayari, M., Safaie, N and Shamsbakhsh, M. 2009. Genetic diversity of Iranian AG1-IA isolates of Rhizoctonia solani, the cause of rice sheath blight, using morphological and molecular markers. Journal of Phytopathology. 157 (11/12): 708-714.

Kumar, Singh, V., Prashant and Vikram, K.N. 2008. Morphological and virulence characterization of Rhizoctonia solani causing sheath blight of rice. Environment and Ecology. 26 (3): 1158-1166.

Kuninaga, S., Yokosawa, R and Ogoshi, A. 1978. Anastomosis grouping of Rhizoctonia solani Kuhn, isolated from non-cultivated soil. Annual Phytopathological Society of Japan. 44: 591-598.

Lal, M., Singh, V., Kandhari, J and Sharma, P. 2014. Diversity analysis of Rhizoctonia solani causing sheath blight of rice in India. African Journal of Biotechnology. 13 (51): 4594- 4605.

Matsumoto, T. 1921. Studies on the physiology of the fungi XII. Physiological specialization in 
Rhizoctonia solani Kuhn. Annual Missouri Botany Garden. 8: 1-62.

Moni, Z.R., Ali, M.A., Alam, M.S., Rahman, M.A., Bhuiyan, M.R., Mian, M.S., Iftekharuddaula, K.M., Latif, M.A and Khan, M.A.I. 2016. Morphological and genetical variability among Rhizoctonia solani isolates causing sheath blight disease of rice. Rice Science. 23 (1): 42 50

Neeraja, C. N., Shenoy, V.V., Reddy, C.S and Sarma, N.P. 2002a. Isozyme polymorphism and virulence of Indian isolates of the rice sheath blight fungus. Mycopathologia. 156 (2): 101-108.

Neeraja, C. N., Vijayabhanu, N., Shenoy, V.V., Reddy, C.S and Sarma, N.P. 2002b. RAPD analysis of Indian isolates of rice sheath blight fungus Rhizoctonia solani. Journal of Plant Biochemistry and Biotechnology. 11 (1): 43-48

Ogoshi, A. 1987. Ecology and pathogenicity of anastomosis and intraspecific groups of Rhizoctonia solani Kuhn. Annual Review of Phytopathology. 25: 125143.

Sharma, M., Gupta, S.K and Sharma, T.R. 2005. Characterization of variability in Rhizoctonia solani by using morphological and molecular markers. Journal of Phytopathology. 153: 449456.

Singh, V., Kumar, S., Lal, M and Hooda, K.S. 2014. Cultural and morphological variability among Rhizoctonia solani isolates from trans-gangetic plains of India. Research on Crops. 15 (3): 644650.

Singh, V., Singh, U.S., Singh, K.P., Singh, M and Kumar, A. 2002. Genetic diversity of Rhizoctonia solani isolates from rice: differentiation by morphological characteristics, pathogenicity, anastomosis behaviour and RAPD fingerprinting. Journal of Mycology and Plant Pathology. 32: 332-344.

Sneh, B., Burpee, L and Ogoshi, A. 1991. Identification of Rhizoctonia species. Annuals of Phytopathological Society Press, St. Paul, Minnesota. 133.

Sundravadana, S., Thirumurugan, $\mathrm{S}$ and Alice, D. 2011. Exploration of Molecular Variability in Rhizoctonia bataticola, the incident of root rot disease of pulse crops. Journal of Plant Protection Research. 51 (2): 184-189.

Susheela, K., Reddy, C.S., Biradar, S.K., Sundaram, R.M., Balachandran, S.M. and Neeraja, C.N. (2004). Variation among the isolates of Rhizoctonia solani, causing sheath blight disease in rice. Pages 119-121 in: 9th National Rice Biotechnology Network Meeting, IARI, New Delhi, from April 15-17, 2004.

Swain, N.C., Chhotray, A.K and Mahapatra, S.S. 2005. Pathogenic variability of Rhizoctonia solani causing sheath blight of rice and its management. Journal of Plant Protection and Environment. 2 (1): 96-99

Thakur, R.S., Sugha, S.K and Sharma, B.M. 1992. Morphological grouping of different isolates of Rhizoctonia solani. Kuhn. Plant Disease Research. 7 (1): 58-60.

Thind, T.S and Aggarwal, R. 2008. Characterization and pathogenic relationships of Rhizoctonia solani isolates in a potato-rice system and their sensitivity to fungicides. Journal of Phytopathology. 156 (10): 615-621.

Toda, T., Hyakumachi, M and Arora, D.K. 1999. Genetic relatedness among and within different Rhizoctonia solani anastomosis groups as assessed by RAPD, ERIC and REP-PCR. Microbiological Research. 154 (3): 247258 
Upadhyay, B.K., Dubey, S.C., Singh, R and Tripathi, A. 2013. Morpho-molecular characterization of Indian isolates of Rhizoctonia solani infecting mungbean. Research Journal of Biotechnology. 8 (11): 92-99.

Xiao Y, Liu M, Li G, Zhou E, Wang L, Tang J, Tan F, Zheng A, Li P. 2008. Genetic diversity and pathogenicity varia- tion in Rhizoctonia solani isolates from rice in Sichuan Province, China. Rice Sciences. 15: 137-144.

Yu, J.F., Zhang, X.G, Li, H.M. and Zhang, T.Y. (2003). Genetic variation of isolates of Rhizoctonia solani AG-1 in Yunnan Province. Mycosystema 22: 6973.

Yugander, A., Ladhalakshmi, D., Prakasham, V., Satendra, K. Mangrauthia, Prasad,
M.S., Krishnaveni, D., Madhav, M.S., Sundaram, R.M and Laha, G.S. 2015. Pathogenic and Genetic Variation among the Isolates of Rhizoctonia solani (AG 1-IA), the Rice Sheath Blight Pathogen. Journal of Phytopathology. 163: 465- 474.

Zhang, M and Dernoeden, P.H. 1995. Facilitating anastomosis grouping of Rhizoctonia solani isolates from coolseason turf grasses. Hort. Science. 30: 1260-1262.

Zhou, E.X., Cao, J.X., Yang, $M$ and Zhu, X.R. 2002. Studies on the genetic diversity of Rhizoctonia solani AG-1-IA from six provinces in the southern China. Journal of Nanjing Agricultural University. 25: 36-40.

\section{How to cite this article:}

Manjunatha, O., B. Vidya Sagar, V. Prakasam and Narendra Reddy, C.N. 2018. Variability Studies on Sheath Blight of Rice in Karnataka, India. Int.J.Curr.Microbiol.App.Sci. 7(10): 724736. doi: https://doi.org/10.20546/ijcmas.2018.710.080 